\title{
GENOTYPE VARIABILITY AND HAPLOTYPE PROFILE OF ABCB1 (MDR1) GENE POLYMORPHISMS IN MACEDONIAN POPULATION
}

\author{
Zorica Naumovska ${ }^{1}$, Aleksandra K. Nestorovska ${ }^{1}$, Zoran Sterjev ${ }^{1}$, Ana Filipce ${ }^{2}$, \\ Aleksandar Dimovski ${ }^{1}$, Ljubica Suturkova ${ }^{1}$
}

${ }^{1}$ Institute for Pharmaceutical Chemistry, Faculty of Pharmacy, University Ss. Cyril and Methodius, Skopje, R. Macedonia

${ }^{2}$ University Clinic of Psychiatry, Medical Faculty, University Ss. Cyril and Methodius, Skopje, R. Macedonia

Corresponding Author: Zorica Naumovska, Faculty of Pharmacy, University "Ss. Cyril and Methodius", Skopje, Mother Theresa 17, 1000 Skopje, R. Macedonia; Tel: +389 (0)2 31260 32; +389 (0)2 0754977 51; E-mail: zose@ff.ukim.edu.mk

\begin{abstract}
The aim of this study was to evaluate the most common ABCBI (MDR1, P-glycoprotein) polymorphisms in the population of R. Macedonia and compare the allele and haplotype frequencies with the global geographic data reported from different ethnic populations. The total of 107 healthy Macedonian individuals from the general population was included.

Genotypes for the $A B C B 1$ for three polymorphisms C1236T [rs1128503], G2677A/T [rs2032582] and C3435T [rs1045642] were analyzed by Real-Time PCR. Obtained allele frequencies for these three SNPs were similar to those observed in other European Caucasians. The detected genotype frequencies were $33.6 \%$ for $1236 \mathrm{CC}, 44.9 \%$ for $1236 \mathrm{CT}$ and $21.5 \%$ for $1236 \mathrm{TT}$ in exon $12 ; 32.7 \%$, $44.9 \%$ and $22.4 \%$ for $2677 \mathrm{GG}, 2677 \mathrm{GT}$ and $2677 \mathrm{GT}$ consecutively in exon 21 ; and $25.2 \%$ for $3435 \mathrm{CC}, 52.3 \%$ for $3435 \mathrm{CT}$ and $22.5 \%$ for $3435 \mathrm{TT}$ in exon 26.Strong LD was observed in our study

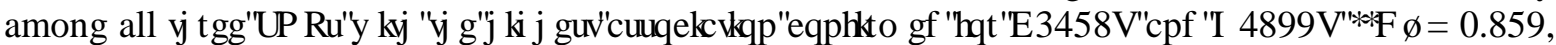
$\mathrm{r}^{2}=0.711$ ). Eight different haplotypes were identified and the most prominent was the CGC haplotype (45.3\%). Our study was the first to have documented the distribution of $A B C B 1$ alleles, genotypes and haplotypes in the population of R. Macedonia. The obtained results can help in the prediction of different response to the drugs that are P-glycoprotein substrates. Additionally, in the era of individualized medicine the determination of the P-glycoprotein genotype might be a good predictive marker for determination of the subpopulations with higher risk to certain diseases.
\end{abstract}

Key words: $A B C B 1$ (MDR1), P-glycoprotein, C1236T, G2677A/T, C3435T, interethnic differences, haplotypes Macedonian population

\section{Introduction}

$\mathrm{ABC}$ transporters play a major role in host detoxification and protection against xenobiotics and their importance is highly substratedependent. P-gp is a pivotal member of $\mathrm{ABC}$ transporters for pharmacological profile of many drugs. Among the 48 genes, forming 7 different subfamilies (A-G) based on sequence similarities, in the ATP-binding cassette (ABC) $A B C B 1$ (MDRl, P-glycoprotein) gene is the first identified and the best characterized. This gene encodes transmembrane protein that mediates ATP-dependent transport of various molecules. It is located in the chromosome $7 \mathrm{q} 21.1$ and consists of 28 translated exons and 27 introns with over $100 \mathrm{~kb}$. It is 1280 amino acid polypeptide assembled in two nearly homogeneous halves, each containing six transmembrane spanning domains and one ATP binding domain [1]. P-gp is $170 \mathrm{kDa}$ transmembrane 
protein and is widely expressed in normal tissue. The distribution of P-gp includes the epithelial cells lining the luminal surface of enterocytes in the lower gastrointestinal tract (jejunum, ileum and colon), influence the absorption and limit the bioavailability of variety of structurally diverse drugs. P-glycoprotein expression on the canicular surface of hepatocytes and the apical surface of epithelial cells of proximal renal tubules influence the metabolism and secretion of toxic xenobiotic, drugs and their metabolites. P-gp distribution on epithelial cells of placenta on the maternal blood flow side plays protective role for the child, whereas P-gp expression in the luminal surface of capillary endothelial cells of the blood-brain barrier (BBB) transport the toxic compounds out of the brain and effectively prevent the uptake $[1,2]$. This transport protein is expressed and translocated to membranes of lymphocytes and hematopoietic stem cells where it contributes to decreased response in HIV and leukemia treatment [3-5]. P-gp can influence bioavailability and therapeutic response of many drugs, such as drugs including anticancer, antiarrhythmic, glucocorticoids, antipsychotics, antiepileptic's, antidepressants, opioids and many other $[6,7]$.

The MDRl gene is highly polymorphic. To date, 4456 SNPs are listed in the NCBI database, out of which 367 are in the coding region. According to PharmGKB, 41 are missense SNPs and 124 polymorphic sites have allele frequency higher than 5\% [3, 8]. Polymorphic variations on $A B C B 1$ (MDRl) gene influence on its expression $[9,10]$, on their association with pharmacokinetics and bioavailability of drugs $[11,12]$ and on their association with clinical effects $[13,14]$. Among 68 SNPs genotyped in various ethnical populations, 17 SNPs are in 5'-region, 19 in exonic regions (14 missense and 5 silent SNPs), 25 in intronic regions and 13 in the 3'-untranslated region (UTR) [3]. Intronic SNPs usually alter mRNA generation, integrity or processing. On the other hand SNPs on the coding region may alter the protein structure directly by amino-acid substitution (non-synonymous SNPs) or altering the mRNA sequence, its structure and stability despite coding the same amino acid (synonymous SNPs) [15]. DNA variations may influence the inter-individual differences in treatment response, alternation of drug efficacy and onset of adverse side effects in patients with specific genetic profile.

Beside the huge number of identified SNPs in $A B C B 1$ gene, most studies are focused on three SNPs, namely $1236 \mathrm{C}>\mathrm{T}$ in exon 21 and $3435 \mathrm{C}>\mathrm{T}$ in exon 26 that are synonymous, and $2677 \mathrm{G}>$ T/A in exon 21 that is nonsynonymous triallelic polymorphism responsible for Ser to Ala/Thr amino acid substitution at position 893. They are in high linkage disequilibrium [16] and the frequencies of these allelic variations occur at different frequencies among populations and subpopulations of different ethnic or racial origin. 1236C > T SNP refers to the glycine residue located in the external surface of the N-terminal domain (NBD). 3435C > T correlates to isoleucine residue located in the internal regions of $\mathrm{C}$-terminal NBD. This non-synonymous variation is associated with altered P-gp activity. To date there have been vast number of reports correlating the presence of these three SNPs with treatment response and disease predisposition and progression (renal tumor, Chron's disease and ulcerative colitis, Parkinson's disease, schizophrenia, Alzheimer, HIV infection) [9, 17-21]. Most common approach in determination of the influence of gene variation is haplotype assessment because it may provide a better understanding of the observed inconsistences and are promising predictor of the functional consequences of $A B C B 1$ polymorphisms. It has been confirmed that the use of $A B C B 1$ haplotypes is superior in prediction of the pharmacokinetics of digoxin [22], cyclosporine [23] and fexofenadine [24], as well as intestinal expression of $A B C B 1$ mRNA [25]. A correlation was observed between the 1236T, 2677T and 3435T haplotype and decreased irinotecan clearance in Japanese patients with cancer. Also, 2677GG genotype and 2677G-3435C haplotype were associated with significantly better chemotherapy response [26].

The aim of our study is to estimate the genotype and haplotype frequencies for C1236T, G2677T/A and C3435T polymorphisms in healthy Macedonian individuals in order to provide useful findings that might help in future studies on bioavailability and pharma- 
cokinetics of drugs, interindividual treatment response variations, as well as prevalence of some certain pathologies.

\section{Martials and methods}

The study included 107 unrelated healthy ethnical Macedonians of both sexes (76 males and 31 females) from Republic of Macedonia. DNA samples were selected from the DNA bank in the Centre for Bimolecular and Pharmaceutical Analysis (CBPA) in the Faculty of Pharmacy in Skopje from individuals that were previously enrolled in other research studies that were approved by Ethical committee of the Faculty of Pharmacy University "Ss. Cyril and Methodius", Skopje, Republic of Macedonia. DNA samples were tested anonymously with previously removed personal data. All procedures were conducted in accordance with Declaration of Helsinki.

\section{DNA isolation}

The genomic DNA was extracted from peripheral lymphocytes in the blood samples obtained in EDTA vacutainers, using Proteinase $\mathrm{K}$ digestion, phenol chloroform extraction and ethanol precipitation. DNA yields and purity were measured at $260 \mathrm{~nm}$ and 260/280 nm respectively (NanoDrop 2000, Thermo Scientific) and DNA integrity was confirmed with electrophoresis on $1 \%$ agarose gels, stained with ethidium bromide.

\section{Genotyping}

The genotyping was performed with Real-Time PCR based on the allelic discrimination method (MxPRo 3005P, Staratgene, La Jolla, CA, USA) using TaqMan SNP genotyping assay for C1236T (rs1128503 assay ID C_7586662_10), G2677A/T (rs2032582 assay ID C_11711720_C_30 and C_11711720_C_ 40) and C3435T (rs1045642 assay ID C_7586657_20) according to the guidelines of the manufacturer (Life Technologies, USA).

\section{Data Analysis}

Statistical analysis was performed using SPSS software (v. 22). The genotype distributions were assessed for the Hardy-Weinberg equilibrium (HWE) with $\chi^{2}$ test using an online calculator (http://ihg.gsf.de/cgi-bin/hw/hwa1.pl). Statistical analysis for allele and genotype fre- quencies between our and other ethnic populations was evaluated with Chi-squared analysis and Fisher exact probability test. Odds ratios (OR) were calculated with $95 \%$ confidence interval limits $(95 \% \mathrm{CI})$. The level of statistical significant was defined as $\mathrm{p} \leq 0.05$. Linkage disequilibrium (LD) between SNP pairs in the population was estimated by Lewontin's coefficient $\left(D\right.$ ') and Pearson 's correlation $\left(r^{2}\right)$ (Lewontin and Kojima, 1960; Lewontin 1964). The statistical analyses were performed with SHEsis software platform for analysis of LD, haplotype and genetic association at polymorphism loci (http://analysis2.bio-x.cn/myAnalysis.php) [27, 28].

\section{Results}

The distributions of the $A B C B 1$ allele, genotype and haplotype frequencies of C1236T, G2677T/A and C3435T genetic variations in $A B C B 1$ gene for Macedonian healthy population are summarized in Table 1. All the determined distributions were in agreement with those predicted by the Hardy-Weinberg equilibrium. According to our results, the frequencies of wild-type alleles for C1236T (56\%), G2677T/A (55\%) and C3435T (51\%) in our study were similar to the general frequencies reported for the Caucasians of European descendant, but differ from those of Asian and African population.

Frequencies of the wild-type $\mathrm{C}$ and mutant $\mathrm{T}$ alleles on 1236 locus were $56.07 \%$ and $43.93 \%$ respectively. The observed genotype frequencies were $33.6 \%, 44.9 \%$ and $21.5 \%$ for $1236 \mathrm{CC}, 1236 \mathrm{CT}$ and $1236 \mathrm{TT}$ in exon 12. None of the examined individuals was carrier of mutant A allele at position 2677, so the allelic distribution for this position were $55.14 \%$ for $\mathrm{G}$ allele and $44.86 \%$ for the mutant $\mathrm{T}$ allele. The observed genotype frequencies were $32.7 \%$, $44.9 \%$ and $22.4 \%$ for $2677 \mathrm{GG}, 2677 \mathrm{GT}$ and 2677GT consecutively. Allelic frequencies in exon 26 were $51.4 \%$ for $\mathrm{C}$ allele and $48.6 \%$ for mutant $\mathrm{T}$ allele, whereas the observed genotype frequencies were $25.2 \%$ for $3435 \mathrm{CC}, 52.3 \%$ for $3435 \mathrm{CT}$ and $22.5 \%$ for $3435 \mathrm{TT}$.

When analyzing the linkage between C1236 and G2677T the most frequent genotype was CT-GT (39\%) fallowed by CC-GG (29\%) 


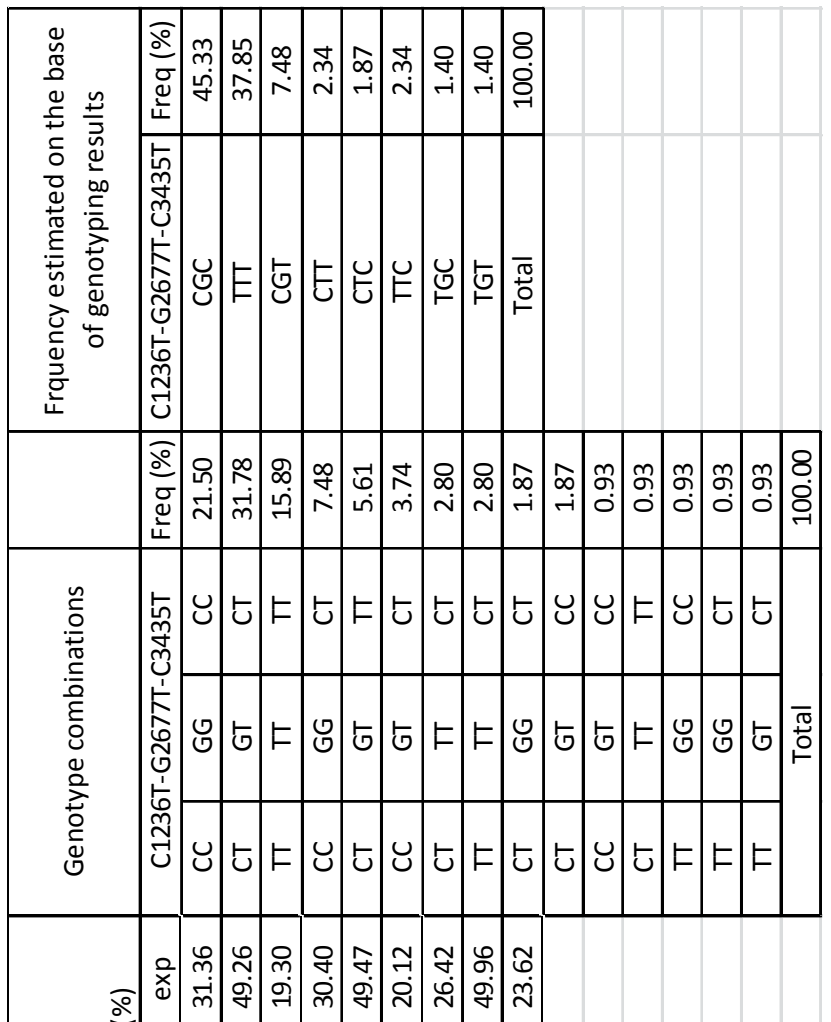

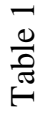

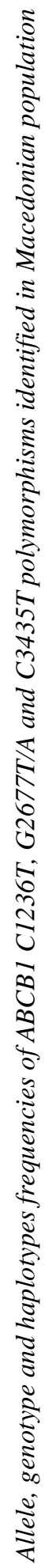

- 㐅 ஓं

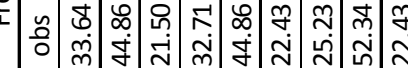

๘

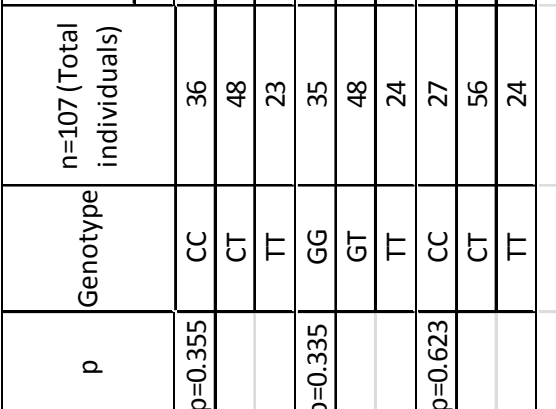

$-2$

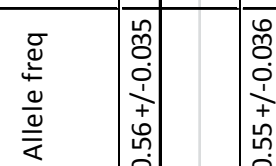

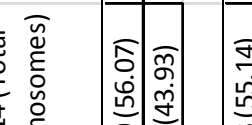

तI

$\frac{\frac{\varrho}{\omega}}{\frac{\bar{\alpha}}{4}}$

त्रे बे न्व

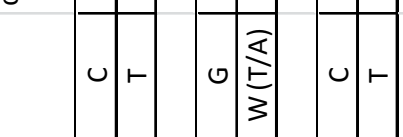

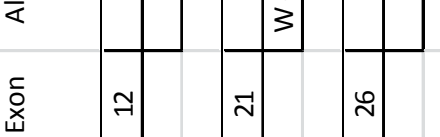


and TT-TT (20\%) (Table 2). Considering the genotype observed between G2677T/C3435T and C1236T/C3435T SNPs we obtained exactly the same frequencies. The highest frequencies were CT-GT (36\%), than CC-GG (22\%) and TT-TT (17\%). The haplotype combinations and their frequencies estimated on the base of geno- type combination are presented in the table 2 . The most frequent haplotypes were $1236 \mathrm{C}$ $2677 \mathrm{G}$ (51\%), 1236C-3435C (47\%) and 2677C-3435T (47\%), followed by the mutant variants $1236 \mathrm{~T}-2677 \mathrm{~T}$ (41\%), 1236T-3435T (41\%) and 2677T-3435T (40\%).

Table 2

Frequencies of different genotype combinations and haplotypes between different pairs of C1236T, G2677T and C3435T Polymorphisms identified in Macedonian population

\begin{tabular}{c|c|c|c|c|c|c|c|c|} 
& $2677 \mathrm{GG}$ & Freq (\%) & $2677 \mathrm{GT}$ & Freq (\%) & $2677 \pi$ & Freq (\%) & Haplotype & $\begin{array}{c}\text { Frquency estimated on } \\
\text { the base of genotyping } \\
\text { results (\%) }\end{array}$ \\
\hline $1236 \mathrm{CC}$ & 31 & 28,97 & 5 & 4,67 & 0 & 0,00 & $1236 \mathrm{C}-2677 \mathrm{G}$ & 51,87 \\
\hline $1236 \mathrm{CT}$ & 2 & 1,87 & 42 & 39,25 & 4 & 3,74 & $1236 \mathrm{C}-2677 \mathrm{~T}$ & 4,21 \\
\hline $1236 \mathrm{TT}$ & 2 & 1,87 & 1 & 0,93 & 20 & 18,69 & $1236 \mathrm{~T}-2677 \mathrm{G}$ & 3,27 \\
\hline & & & & & & & $1236 \mathrm{~T}-2677 \mathrm{~T}$ & 40,65 \\
\hline
\end{tabular}

\begin{tabular}{c|c|c|c|c|c|c|c|c|}
\hline & $2677 G G$ & Freq (\%) & 2677GT & Freq (\%) & $2677 \pi$ & Freq (\%) & Haplotype & $\begin{array}{c}\text { Frquency estimated on } \\
\text { the base of genotyping } \\
\text { results (\%) }\end{array}$ \\
\hline $3435 \mathrm{CC}$ & 24 & 22,43 & 3 & 2,80 & 0 & 0,00 & $2677 \mathrm{G}-3535 \mathrm{C}$ & 47,20 \\
\hline $3435 \mathrm{CT}$ & 11 & 10,28 & 39 & 36,45 & 6 & 5,61 & $2677 \mathrm{G}-3435 \mathrm{~T}$ & 7,94 \\
\hline $3435 \pi$ & 0 & 0,00 & 6 & 5,61 & 18 & 16,82 & $2677 \mathrm{~T}-3435 \mathrm{C}$ & 4,21 \\
\hline & & & & & & & $2677 \mathrm{~T}-3435 \mathrm{~T}$ & 40,65 \\
\hline
\end{tabular}

\begin{tabular}{c|c|c|c|c|c|c|c|c|}
\hline & $3435 \mathrm{CC}$ & Freq (\%) & $3435 \mathrm{CT}$ & Freq (\%) & $3435 \mathrm{TT}$ & Freq (\%) & Haplotype & $\begin{array}{c}\text { Frquency estimated on } \\
\text { the base of genotyping } \\
\text { results (\%) }\end{array}$ \\
\hline $1236 \mathrm{CC}$ & 24 & 22,43 & 12 & 11,21 & 0 & 0,00 & $1236 \mathrm{C}-3435 \mathrm{C}$ & 47,20 \\
\hline $1236 \mathrm{CT}$ & 2 & 1,87 & 39 & 36,45 & 7 & 6,54 & $1236 \mathrm{C}-3435 \mathrm{~T}$ & 8,88 \\
\hline $1236 \mathrm{~T}$ & 1 & 0,93 & 5 & 4,67 & 17 & 15,89 & $1236 \mathrm{~T}-3435 \mathrm{C}$ & 4,21 \\
\hline & & & & & & & $1236 \mathrm{~T}-3435 \mathrm{~T}$ & 39,72 \\
\hline
\end{tabular}

Pairwise LD profile for the three SNPs using $D^{\prime}$ and $r^{2}$ values are presented in Figure 1 , and summarized in (Table 3). All three SNPs in Macedonian population are in high Linkage Disequilibrium. The strongest correlation was observed between C1236T and G2677T (D' = $\left.0.859, \mathrm{r}^{2}=0.711\right)$ followed by $\mathrm{G} 2677 \mathrm{~T}$ and C3435T ( $\left.D^{\prime}=0.802, r^{2}=0.534\right)$ and $C 1236 \mathrm{~T}$ and C3435T ( $\left.D^{\prime}=0.795, r^{2}=0.802\right)$.
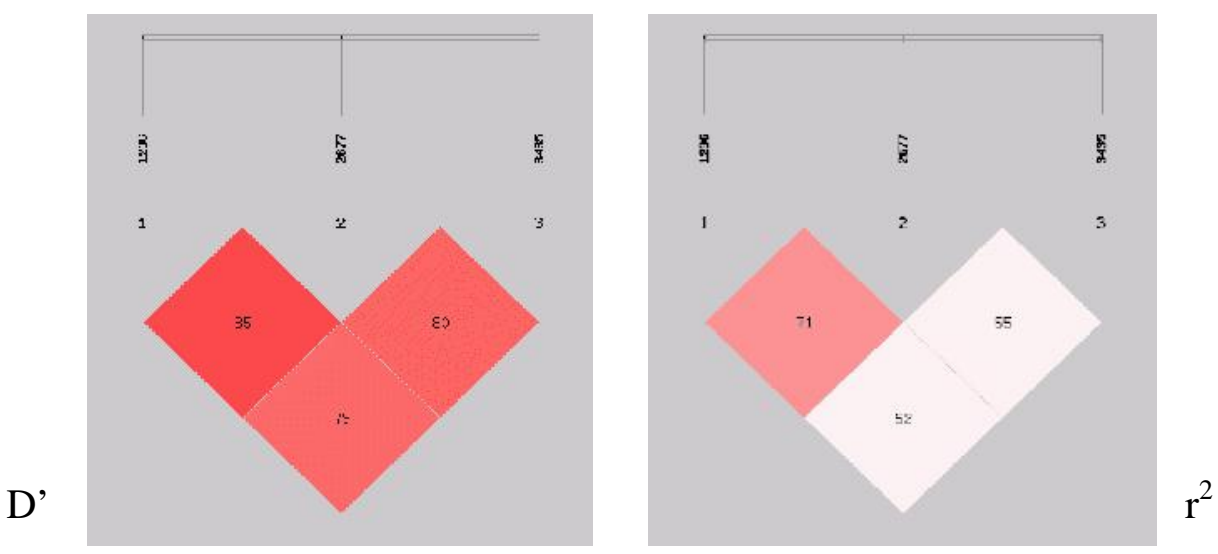

Figure 1 - Pairwise LD profile for C1236T, G2677T and C3435T SNPs 
Table 3

Tabular presentation of $L D$ profile for C1236T, G2677T and C3435T SNPs

\begin{tabular}{l|l|l|l|l|} 
& C1236T & G2677T & C3435T & \\
\hline C1236T & & 0.859 & 0.795 \\
\hline G2677T & 0.711 & & 0.802 \\
\hline C3435T & 0.524 & 0.554 & \\
\hline
\end{tabular}

In our study 15 different genotype combinations among C1236, G2677T and C3435T SNPs were found, as far as we didn't identified carrier of 2677A mutant allele. Genotype combinations that were observed with frequencies higher than 3\% were the following CT-GT-CT $(31,8 \%)$, CC-GG-CC(21.5\%), TT-TT-TT (15, 9\%), CC-GG-CT (7.5\%), CT-GT-TT (5.6\%) and CC-GT-CT $(3.7 \%)$ (Table1). In a population of healthy subjects of Macedonian ethnicity these three SNPs were structured in eight different haplotypes. The haplotype combinations CGC with $45.3 \%$, TTT with $37.8 \%$ and CGT with $7.5 \%$ in our examined population were the most prominent.

\section{Discussion}

In recent years, there are vast numbers of published data that report interesting evidence for the influence of SNPs in the $A B C B 1$ gene on P-gp function. These polymorphic variants are potential determinants of inter-individual and inter-ethnical variability in drug response [29-31] and susceptibility to certain diseases.

In this study, we analyzed the three most common C1236T, G2677T/A and C3435T SNPs of $A B C B 1$ gene and we present the allele, genotype and haplotype frequencies in comparison with the general frequencies reported for other population.

The detected frequency of the wild type allele $1236 \mathrm{C}$ in exon 12 in population of ethnic Macedonians was $56.07 \%$ and it was similar to the general frequencies reported for the various ethnic groups throughout Europe; (52-58\%). (Table 4) The literature data point to similar allele frequency of $1236 \mathrm{C}$ in our population $(56 \%)$ and those reported for the Czech $(51 \%)$, Serbians $(0.53 \%)$, Hungarians $(55 \%)$, Polish and French (57\%), German and Polish (58\%) populations, but in disagreement with the frequencies reported for the Romanian population
(44\%) $\left(x^{2}=5.79, \mathrm{p}=0.01505\right)$ and Slovenian population (39\%) $\left(\chi^{2}=5.79, \mathrm{p}=0.01614\right)$. Wild type allele is most frequently observed in Moroccans (62.5\%) and other African population, such as in Sub-Saccharin Africans where it estimates $88 \%$. In Asian population the mutant $\mathrm{T}$ allele is more common and its frequency ranges among 59\% in Chinese Uygur, 65\% in Chinese Han and Japanese and $71 \%$ in Chinese population.

Homozygous mutant 1236TT genotype has been linked with reduced clearance of docetaxel [45] as well as, with better response to imatnib in patients with chronic myeloid leukemia (CML) [18].

The allelic frequencies of $55 \%$ for $2677 \mathrm{G}$ allele on exon 21 was found in our population. We fail to detect the mutant $\mathrm{A}$ allele in locus 2677, and this finding is in line with previously published data where this allele is absent in most of the European populations [32, 30]. The absence of this allele might have been result of small population size of study group. The 2677A allele is shows higher frequency in East Asia population such as Chinese [23], Japanese [33] and Korean population [34]. As the frequency of mutant $\mathrm{A}$ allele in European population is very low (1-3\%), in our discussion the A allele was pulled with mutant $\mathrm{T}$ allele in "W" allele (Table $4)$. The frequency of $\mathrm{G}$ allele in our population is similar to the frequency of Germans $(56 \%)$ White Italians (56\%), Bulgarian and Hungarians (55\%), Russians (54\%), Serbians (53\%), French (53\%), and no statistically significant difference was observed between the allele frequency in Macedonians and other Europeans. The significant difference was confirmed only for Chinese Han population $\left(x^{2}=3.86\right.$ with $\left.p=0.049\right)$, In$\operatorname{dian}\left(x^{2}=14,59, p=0.00013\right)$, Vietnamese $\left(X^{2}=\right.$ $7.20, \mathrm{p}=0.007)$, Brazilians intermediate $\left(X^{2}=\right.$ $10.69, p=0.00108)$ and the highest difference was confirmed for Brazilians-black $\left(x^{2}=32.29\right.$, $\mathrm{p}<0.0000001)$. Pharmacogenetic studies of this locus have confirmed that patients with nonsmall cell lung cancer that have $2677 \mathrm{GG}$ variant have better treatment response to chemotherapy in comparison to carriers of other genotypes [35]. Gonzales et al., [36] didn't confirm association between $A B C B 1$ polymorphisms with systemic lupus erythematosus (SLE), the evaluation of these polymorphisms is suggested, and especially the SNP2677 since the mutant allele can affect clinical features of this disease. 
Table 4

Comparison of allele and genotype frequencies of ABCB1 C1236T, G2677T/A and C3435T polymorphisms reported for different ethnic population

\begin{tabular}{|c|c|c|c|c|c|c|c|c|c|c|c|c|c|}
\hline & & \multicolumn{3}{|c|}{ C1236T } & \multicolumn{5}{|c|}{$G 2677 \mathrm{~W}(\mathrm{~A} / \mathrm{T})$} & \multicolumn{3}{|c|}{ C3435T } & \multirow[t]{2}{*}{ ref } \\
\hline & $n$ & $\begin{array}{l}\text { allale } \\
\text { freq C } \\
(\%)\end{array}$ & $\begin{array}{l}\text { allale } \\
\text { freq T } \\
(\%)\end{array}$ & $p$ value & $\begin{array}{c}\text { allele } \\
\text { freq G } \\
(\%)\end{array}$ & $\begin{array}{c}\text { allale } \\
\text { freq T } \\
(\%)\end{array}$ & $\begin{array}{c}\text { allale } \\
\text { freq A } \\
(\%)\end{array}$ & $\begin{array}{c}\text { allele } \\
\text { freq W } \\
\text { (\%) }\end{array}$ & p value & $\begin{array}{c}\text { allele } \\
\text { freq C } \\
(\%)\end{array}$ & $\begin{array}{l}\text { allele } \\
\text { freq T } \\
(\%)\end{array}$ & p value & \\
\hline $\begin{array}{l}\text { Macedonian } \\
\text { healthy } \\
\text { individuals }\end{array}$ & 107 & 56,07 & 43,93 & & 55,14 & 45,00 & 0,00 & 44,86 & & 51,40 & 48,60 & & this study \\
\hline $\begin{array}{l}\text { European } \\
\text { descedants }\end{array}$ & 60 & 60,83 & 39,17 & & 60,83 & 37,00 & 2,00 & 39,17 & & n.d & $n . d$ & & HapMap-CEU \\
\hline $\begin{array}{l}\text { Caucasians, } \\
\text { Germany }\end{array}$ & 188 & 62,77 & 37,23 & & n.d. & n.d. & n.d. & n.d. & & 51,60 & 47,87 & & [9] \\
\hline Germans & 461 & 58,57 & 40,56 & & 56,51 & 41,00 & 2,00 & 43,49 & & 46,10 & 54,12 & & [57] \\
\hline Crech & 189 & 51,85 & 41,27 & & 54,23 & 45,80 & 0,30 & 46,30 & & 43,65 & 56,35 & & [32] \\
\hline Polish & 139 & 58,63 & 41,37 & & 60,43 & 39,00 & 1,00 & 40,00 & & 32,73 & 55,76 & & [58] \\
\hline Polish & 96 & 57,29 & 42,71 & & 59,90 & 40,00 & n.d & 40,10 & & 53,13 & 46,88 & & [37] \\
\hline Polish & 204 & n.d. & n.d. & & 60,54 & 38,00 & 2,00 & 40,00 & & 47,55 & 52,45 & $\begin{array}{c}x 2=7.72 \\
p=0.00545\end{array}$ & [50] \\
\hline Russians & 290 & n.d. & n.d. & & 54,48 & 41,90 & 3,30 & 45,52 & & 45,52 & 54,48 & & [59] \\
\hline Slovenian & 355 & 38,73 & 61,27 & $\begin{array}{c}x^{2}=5.79 \\
p=0.01614\end{array}$ & 59,72 & 40,00 & n.d & 40,28 & & 47,18 & 53,10 & & {$[46]$} \\
\hline Caucasians, UK & 190 & n.d. & n.d. & & n.d. & n.d. & n.d. & n.d. & & 48,16 & 51,84 & & {$[60]$} \\
\hline British & 280 & n.d. & n.d. & & 57,86 & 39,60 & 2,50 & 42,10 & & 46,07 & 53,93 & & [61] \\
\hline Scottish & 370 & n.d. & n.d. & & 51,62 & 49,00 & n.d & 49,46 & & 47,43 & 52,57 & & [62] \\
\hline French & 223 & 57,62 & 42,38 & & 53,81 & 42,40 & 2,60 & 44,84 & & 53,36 & 46,19 & & [63] \\
\hline Spanish & 408 & n.d. & n.d. & & n.d. & n.d. & n.d. & n.d. & & 51,96 & 48,04 & & [64] \\
\hline Spanish & 204 & n.d. & n.d. & & n.d. & n.d. & n.d. & n.d. & & 52,45 & 47,55 & & {$[65]$} \\
\hline White Italians & 106 & n.d. & n.d. & & 56,13 & 44,00 & n.d & 43,87 & & 53,77 & 46,23 & & {$[66]$} \\
\hline Ittalian & 450 & n.d. & n.d. & & 55,00 & 42,30 & 2,20 & 44,50 & & 52,22 & 47,78 & & {$[67]$} \\
\hline Portuguese & 100 & n.d. & n.d. & & 52,50 & 47,00 & n.d & 47,00 & & 43,00 & 57,00 & & {$[60]$} \\
\hline Serbians & 158 & 53,16 & 46,20 & & 53,48 & 44,30 & 2,22 & 46,52 & & 45,89 & 54,11 & & [44] \\
\hline Bulgarian & 160 & n.d. & n.d. & & 55,94 & 44,00 & n.d & 44,06 & & 49,06 & 50,94 & & [68] \\
\hline Romanians & 465 & 44,19 & 50,22 & $\begin{array}{c}x^{2}=5.91 \\
p=0.01505\end{array}$ & 52,58 & 45,40 & 2,00 & 47,40 & & 51,83 & 48,17 & & [69] \\
\hline Hungarian & 503 & 55,67 & 44,30 & & 54,77 & 44,10 & & 45,20 & & 47,32 & 52,68 & & {$[37]$} \\
\hline \multicolumn{14}{|l|}{ Asians } \\
\hline Japanese & 154 & 34,42 & 65,58 & $\begin{array}{c}x=4.87 \\
p=0.02726\end{array}$ & 42,86 & 40,58 & 16,56 & 57,14 & & 61,36 & 40,58 & $\begin{array}{c}x 2=4.00 \\
p=0.04542\end{array}$ & [73] \\
\hline Japanese & 117 & n.d & n.d & & 36,75 & 35,47 & 13,25 & 48,72 & & 61,54 & 38,46 & $\begin{array}{c}x=4.68 \\
p=0.03055\end{array}$ & [74] \\
\hline Chinese Han & 200 & 34,25 & 65,75 & $\begin{array}{c}x 2=27.29 \\
p=1.755 e-07\end{array}$ & 41,75 & 45,00 & 13,25 & 58,25 & $\begin{array}{c}x=3.86 \\
p=0.04934\end{array}$ & 56,75 & 43,25 & & [75] \\
\hline Chinese Uygur & 161 & 40,68 & 59,32 & $\begin{array}{l}x=12.23 \\
p=0.00047\end{array}$ & 45,03 & 50,62 & 4,35 & 54,97 & & 47,20 & 52,80 & & [76] \\
\hline Chinese Kazakh & 108 & 32,87 & 67,13 & $\begin{array}{c}x 2=23.44 \\
p=1.286 e-06\end{array}$ & 50,93 & 38,89 & 10,19 & 49,07 & & 60,19 & 39,81 & & [76] \\
\hline Chinese Han & 165 & 36,36 & 63,64 & $\begin{array}{c}x^{2}=20.46 \\
p=6.095 e-06\end{array}$ & 44,55 & 42,12 & 13,33 & 55,45 & & 62,12 & 37,88 & & [76] \\
\hline Chinese & 206 & 36,17 & 63,83 & $\begin{array}{c}x 2=22.78 \\
p=1.814 e-06\end{array}$ & 52,18 & 36,41 & 11,41 & 47,82 & & 65,29 & 34,71 & $\begin{array}{l}x^{2}=11.37 \\
p=0.00074\end{array}$ & [58] \\
\hline Chinese & 96 & 28,13 & 71,88 & $\begin{array}{c}x 2=32.28 \\
p=1.333 e-08\end{array}$ & n.d. & n.d. & n.d. & n.d. & & n.d & n.d & & [23] \\
\hline Malay & 92 & 34,24 & 65,76 & $\begin{array}{c}x 2=6.19 \\
p=0.01285\end{array}$ & n.d. & n.d. & n.d. & n.d. & & n.d & n.d & & [23] \\
\hline Indian & 87 & 32,76 & 67,24 & $\begin{array}{c}x 2=71.38 \\
p=2.941 \mathrm{e}-17\end{array}$ & 33,33 & 59,77 & 6,90 & 66,67 & $\begin{array}{c}x^{2}=14.59 \\
p=0.00013\end{array}$ & n.d & n.d & & [23] \\
\hline Chinese & 45 & 31,11 & 68,89 & $\begin{array}{l}x^{2}=15.80 \\
p=0.00007\end{array}$ & n.d & n.d & n.d & n.d & & 60,00 & 40,00 & & [37] \\
\hline Korean & 632 & n.d. & n.d. & & 43,83 & 39,08 & 17,09 & 56,17 & & 60,68 & 39,32 & $\begin{array}{c}x 2=6.53 \\
p=0.01061\end{array}$ & [34] \\
\hline Vietnamese & 142 & n.d. & n.d. & & 59,51 & 34,15 & 6,34 & 40,49 & \begin{tabular}{c|}
$2=7.20$ \\
$p=0.00729$
\end{tabular} & 63,38 & 36,62 & & [34] \\
\hline \multicolumn{14}{|l|}{ Africans } \\
\hline Maroccans & 100 & 67,50 & 32,50 & $\begin{array}{l}x^{2}=17.27 \\
p=0.00003\end{array}$ & 72,50 & 28,00 & 0,00 & 27,50 & \begin{tabular}{c|}
$x^{2}=13.45$ \\
$p=0.00025$
\end{tabular} & 64,50 & 35,50 & $\begin{array}{c}x 2=7.27 \\
p=0.00702\end{array}$ & [78] \\
\hline Sudanese & 51 & n.d. & n.d. & & n.d. & n.d. & n.d. & n.d. & & 74,51 & 29,41 & $\begin{array}{c}x^{2}=40.40 \\
p=2.064 \mathrm{e}-10\end{array}$ & [71] \\
\hline Kenyan & 80 & n.d. & n.d. & & n.d. & n.d. & n.d. & n.d. & & 83,13 & 16,88 & $\begin{array}{c}x=-5.05 \\
p=0.02469\end{array}$ & [71] \\
\hline Ghanaian & 206 & n.d. & n.d. & & n.d. & n.d. & n.d. & n.d. & & 83,98 & 16,99 & \begin{tabular}{c|}
$x^{2}=71.35$ \\
$p=2.990 e-17$
\end{tabular} & [71] \\
\hline $\begin{array}{l}\text { African- } \\
\text { American }\end{array}$ & 88 & n.d. & n.d. & & n.d. & n.d. & n.d. & n.d. & & 83,52 & 16,48 & & {$[7]$} \\
\hline $\begin{array}{l}\text { Sub Sacharan } \\
\text { African }\end{array}$ & 57 & 87,72 & 12,28 & $\begin{array}{c}x^{2}=33.72 \\
p=6.350 e-09\end{array}$ & n.d. & n.d. & n.d. & n.d. & & 88,60 & 11,40 & $\begin{array}{c}x^{2}=44.84 \\
p=2.136 \mathrm{e}-11\end{array}$ & [78] \\
\hline \multicolumn{14}{|l|}{ other } \\
\hline Iranian & 131 & n.d. & n.d. & & n.d & n.d & n.d & n.d & & 46,18 & 64,50 & $\begin{array}{c}x 2=4.65 \\
p=0.03114\end{array}$ & [70] \\
\hline Egyptians & 200 & n.d. & n.d. & & n.d & n.d & n.d & n.d & & 59,75 & 40,25 & $\begin{array}{c}x 2=3.96 \\
p=0.04658\end{array}$ & [7]] \\
\hline Turkish & 107 & 45,79 & 54,21 & & 45,79 & 48,60 & 5,61 & 54,21 & & 47,66 & 52,34 & $\begin{array}{c}x=12.01 p=0.0 \\
0053\end{array}$ & [s1] \\
\hline Turkish & 100 & 45,50 & 54,50 & & 52,00 & 48,00 & 0,00 & 48,00 & & n.d & n.d & & [72] \\
\hline $\begin{array}{l}\text { Ashenazi } \\
\text { Jewish }\end{array}$ & 101 & 57,92 & 42,08 & $\begin{array}{c}x 2=44.34 \\
p=2.762 \mathrm{e}-11\end{array}$ & 59,41 & 41,00 & 0,00 & 40,59 & & 64,36 & 34,65 & $\begin{array}{c}x 2=7.85 \\
p=0.00509\end{array}$ & [80] \\
\hline $\begin{array}{l}\text { Brazilians } \\
\text { (white) }\end{array}$ & 106 & 58,96 & 41,04 & & 61,26 & 38,00 & 1,00 & 37,74 & & 54,72 & 45,28 & & [81] \\
\hline $\begin{array}{l}\text { Brazilians } \\
\text { (intermediate) }\end{array}$ & 114 & 66,67 & 33,33 & $\begin{array}{c}x=4.28 \\
p=0.03866\end{array}$ & 70,18 & 28,00 & 2,00 & 29,82 & \begin{tabular}{c|}
$x^{2}=10.69$ \\
$p=0.00108$
\end{tabular} & 66,67 & 34,21 & $\begin{array}{c}x 2=9.88 \\
p=0.00167\end{array}$ & [81] \\
\hline Brazlians (black) & 100 & 66,50 & 33,50 & $\begin{array}{c}x 2=4.73 \\
p=0.02968\end{array}$ & 82,00 & 18,00 & 1,00 & 19,00 & $\begin{array}{c}x z=32.29 \\
p=1.329 \mathrm{e}-08\end{array}$ & 70,50 & 29,50 & $\begin{array}{l}x 2=15.80 \\
p=0.00007\end{array}$ & [81] \\
\hline
\end{tabular}


The detected frequency of the 3435T variant allele (49\%) was in a range comparable with the frequencies reported among other European populations (ranging from 46\%$56 \%$ ). As it was expected, the variant allele frequency $3435 \mathrm{~T}$ in the $\mathrm{R}$. Macedonia population is significantly higher compared to that of the Asian populations (34\%-43\%) except Chinese Uygur where it estimates $52 \%$ and African population, Sudanese $(30 \%)$, Kenyan, Gahanna and African-Americans (17\%), and Sub-Saharan Africans (11\%). The exception was the frequency reported for Egyptians (40.3\%, 50.2\%) which is similar to the frequencies observed in Caucasian population ( $\mathrm{p}$ values listed in Table 4).

The synonymous C3435T SNP has been associated with altered P-gp activity. The homozigocity of wild type $3435 \mathrm{CC}$ genotype is highest among African population and lowest in sought-west Asians [37]. The high frequencies of the C-allele in Africans imply overexpression of P-gp [38] which may influence drug absorption and bioavailability especially in CNS. So, this polymorphism is important therapeutic and prognostic factor for use of p-gp dependent drugs [35]. Homozygous mutant $3435 \mathrm{TT}$ in exon 26 was associated with higher plasma levels of digoxin and lower P-gp expression compared to wild type 3435CC [9]. Lower expression of P-gp in 3435TT carriers gives better prediction for treatment response to palliative chemotherapy in woman with breast cancer [39]. Simon et al. [40] reported that patients with acute myocardial infarction that are on clopidogrel and are carrying $3435 \mathrm{~T} \mathrm{mu}-$ tant variant have more than five times greater rate for development of adverse events than wild type carriers. On the other hand 3435CC genotype is associated with better prognosis and complete remission of acute myeloid leukemia (AML) [41] and higher predisposition to drug-resistant epilepsy [42]. Similar findings were obtained with fexofenadine in individuals with 3435TT/2677TT haplotype carriers [43], but some other authors failed to confirm this results for the same drugs [41, 44]. $3435 \mathrm{CC} / 2677 \mathrm{GG}$ haplotype has been indicated to be in significant correlation with higher response rate to docetaxel/cisplatin [45] treatment of non-small cell lung cancer. This wild type haplotype also was associated with better response to etoposide-cisplatin treatment of small cell lung cancer. On the other hand Potocnik et al. [46], have reported that patients with 1236TT/3435TT genotypes are associated to higher microsatellite instability in colorectal cancer compared to controls. Beside C3435T is silent mutation, in many studies is reported that mutant 3435T allele influence mRNA stability [47]. On the other hand this variant shouldn't be analyzed separately because it is in high linkage disequilibrium with other the non-synonymous polymorphism, such as G2677T/A and it should be taken in consideration that the variability on the other locus could be associated with altered therapeutic response or disease predisposition [48]. That is the reason why the haplotype determination of $A B C B 1$ gene facilitates better estimation of functional role of $A B C B 1$ gene in treatment response and development and clinical picture of certain diseases. Online available date at www.hapmap.org confirm individual LD pattern for each population for number of different SNPs. Strong LD has been confirmed between the three SNPs in Chinese, Malays and Indian [16], and in Hispanic and non- Hispanic [49]. The results from our study give the evidence that the pairwise haplotype frequencies observed in Macedonian population are in agreement with the reported data for other Europeans (Table 2) [50]. Namely, almost complete LD was observed between C1236T and 2677T ( $\mathrm{D}^{\prime}=0.91 \mathrm{r}^{2}=0.83$ ) and G2677T (D' $\left.=0.0 .89 \mathrm{r}^{2}=0.55\right)$ and C3435T in CEU (Utah residents with Northern and Western European ancestry from the CEPH collection). In ethnical Macedonians the LD was only slightly lower $\mathrm{D}^{\prime}=0.859, \mathrm{r}^{2}=$ 0.711 and $\mathrm{D}^{\prime}=0.795, \mathrm{r}^{2}=0.802$ for $\mathrm{C} 1236 \mathrm{~T}$ and G2677T and G2677T and C3435T, respectively. (Fig. 1, Table 3)

A great inter-ethnical variability in the total number and frequencies of $A B C B 1$ haplotypes has been reported. In the study conducted on $48 A B C B 1$ variants in different ethnic groups, 64 haplotypes that were identified, but 33 of them account for $92 \%$ of chromosomes analyzed. In Caucasian population 25 haplotypes were found compared to 55 haplotypes confirmed in African-Americans, and only 20 haplotypes were identified in both populations [51]. When analyzing the three most common SNPs C1236T, G2677T/A and C3435T in Asian population, 10 haplotypes were identified in Chinese, 9 in Indians and 6 in Malays [16]. Twelve different haplotypes were identified in Roma, 
and 11 in Hungarian population [37]. The most frequent haplotype in our population was CGC $(45.3 \%)$. This finding was similar to haplotype frequency of Ashkenazy Jewish population but it differs from the frequencies reported for the other population Caucasians (36.8\%), Uygur Chinese $(30.1 \%)$, Indian $(28.5 \%)$ and Turkish $(25 \%)$ [52]. The higher frequency of this haplotype is observed because of the highest distribution of the following genotype combinations CT-GT-CT (31.8\%), CC-GG-CC (21.5\%), and CC-GG-CT $(7.5 \%)$ found in Macedonians. The second most frequent haplotype in ethnical Macedonian population is TTT with frequency of $37.8 \%$. This haplotype is considered as the most frequent haplotype in most other populations, Caucasians 41\%, Czech 39.3\%, Roma $36 \%$, and Hungarian $37.5 \%$ [37, 52]. The observed difference is probably observed because genotype TT-TT-TT is reported in $15.9 \%$, of our population. The third most prominent haplotype in Macedonian population was CGT with frequency of $7.5 \%$ which is in agreement with most other populations.

Dulucq et al. [18] confirmed that carriers of 1236C-2677G-3435C haplotype have poorer response to imatinib in treatment of chronic myeloid leukemia (CML). Bandur et al. [53] reported that wild type haplotype of these three SNPs increases the risk of acute rejection of the graft in renal transplant patients. Some clinical studies have shown that 1236T-2677T-3435T haplotype is associated with reduced P-gp expression and activity [54], and in this manner Panczyk et al. [55] confirmed greater risk for colorectal cancer development in population with TTT haplotype. Sai et al. [56] associated this mutant haplotype with poorer irinotecan clearance in various cancers.

Published reports are based mostly on nationality rather than ethnic origin and these results in bias. Interethnic variability, presented in the nations reinforces the need for proper selection of control subjects and points against the use of surrogate control groups for studies involving the association of $A B C B 1$ alleles with adverse drug reactions or predisposition to certain diseases.

\section{Conclusion}

This is the first study reporting $A B C B 1$ polymorphisms and haplotypes in ethnical Macedonian population. Our findings suggest that the allele frequencies in Macedonians are similar to those reported for Caucasians of European descendant and have shown statistically significant differences in comparison with the Asians and African population. We have identified eight different haplotypes in our population but, three haplotypes CGC, TTT and CGT represent almost $90 \%$ of ethnical Macedonians. This study may contribute to population specific data on $A B C B 1$ gene and has to be taken into account in order to for future establishment of the association and functional impact of $A B C B 1$ polymorphisms with various drug responses and disease predispositions in $\mathrm{R}$. Macedonia.

\section{REFERENCES}

1. Franke R.M. Gardner E.R and A. Sparreboom, Pharmacogenetics of Drug Transporters Current Pharmaceutical Desig. 2010; 16: 220-230.

2. Zhu Hao-Jie, Wang Jun-Sheng, Markowitz SJ, Donovan LJ, Gibson BB and DeVane CL. Risperidone and Paliperidone Inhibit P-Glycoprotein Activity In Vitro Neuropsychopharmacology. 2007; 32, 757-764.

3. Bruhn O, Cascorbi I. Polymorphisms of drug transporters $A B C B 1, A B C G 2, A B C C 2$ and $A B C C 3$ and their impact on drug bioavailability and clinical relevance. Expert Opin Drug Metab Toxicol. 2014; 10: 1337-54.

4. Chandler B, Detsika M, Khoo SH, et al. Factors impacting the expression of membrane-bound proteins in lymphocytes from HIV-positive subjects. J Antimicrob Chemother. 2007; 60: 685-9.

5. Svirnovski AI, Shman TV, Serhiyenka TF, et al. $A B C B 1$ and $A B C G 2$ proteins, their functional activity and gene expression in concert with drug sensitivity of leukemia cells. Hematology (Am Soc Hematol Educ Program). 2009; 14: 204-12.

6. Marzolini C, Paus E, Buclin T and Kim R B. Polymorphisms in human MDRl (P-glycoprotein): recent advances and clinical relevance. Clin Pharmacol Ther. 2004; 75 (1): 13-33.

7. Gottesman MM, Hrycyna CA, Schoenlein PV, Germann UA and Pastan I. Genetic analysis of the multidrug transporter. Annu Rev Genet 29; 1995; 607-649.

8. Sugawara I, Kataoka K, Morishita Y, et al. Tissue distribution of P-glycoprotein encoded by a multidrugresistant gene as revealed by a monoclonal antibody. MRK 16. Cancer Res. 48: 1926-1929.

9. Hoffmeyer S, Burk O, von Richter O, Arnold HP, Brockmo“ ller J, Johne A, et al. Functional polymorphism of the human multidrug-resistance gene: multiple sequence variations and correlations of one allele with P-glycoprotein expression and activity in vivo. Proc Natl Acad Sci USA. 2000; 97: 3473-3478.

10. Nakamura T, Sakaeda T, Horinouchi M, Tamura T, Aoyama N, Schirakawa T, et al. Effect of the mutation (C3435T) et exon 26 of the MDR1 gene on expression 
level of $M D R 1$ messenger ribonucleic acid in duodenal enterocytes of healthy Japanese subjects. Clin Pharmacol Ther. 2002; 71: 297-303.

11. Nikisch G, Eap CB and Baumann P. Citalopram enantiomers in plasma and cerebrospinal fluid of $A B C B 1$ genotyped depressive patients and clinical response: a pilot study. Pharmacol Res. 2008; 58: 344-347.

12. Uhr M, Grauer MT, Yassouridis A and Ebinger M. Blood- brain barrier penetration and pharmacokinetics of amitriptyline and its metabolites in p-glycoprotein $(a b c b l a b)$ knock-out mice and controls. J Psychiatr Res. 2007; 41: 179-188.

13. Gex-Fabry M, Eap CB, Oneda B, Gervasoni N, Aubry JM, Bondolfi G, et al. CYP2D6 and $A B C B 1$ genetic variability: Influence on paroxetine plasma level and therapeutic response. Ther Drug Monit 2008; 30: 474-482.

14. Loscher W and Potschka H. Role of multidrug transporters in pharmacoresistance to antiepileptic drugs. $\mathrm{J}$ Pharmacol Exp Ther. 2002; 301: 7-14.

15. Wolf SJ, Bachtiar M, Wang J, Sim TS, Chong SS and Lee CGL, An update on $A B C B 1$ pharmacogenetics: insights from a $3 \mathrm{D}$ model into the location and evolutionary conservation of residues corresponding to SNPs associated with drug pharmacokinetics. The Pharmacogenomics Journal. 2011; 11: 315-325.

16. Tang K, Ngoi SM, Gwee PC, Chua JM, Lee EJ, Chong SS et al. Distinct haplotype profiles and strong linkage disequilibrium at the $M D R I$ multidrug transporter gene locus in three ethnic Asian populations. Pharmacogenetics. 2002; 12: 437-450.

17. Kim DH, Lee NY, Sung WJ, Baek JH, Kim JG, Sohn SK, et al. Multidrug resistance as a potential prognostic indicator in acute myeloid leukemia with normal karyotypes. Acta Haematol. 2005; 114(2): 78-83.

18. Dulucq S, Bouchet S, Turcq B, Lippert E, Etienne G, Reiffers $\mathrm{J}$, et al. Multidrug resistance gene (MDRI) polymorphisms are associated with major molecular responses to standard-dose imatinib in chronic myeloid leukemia. Blood. 2008; 112: 2024-2027.

19. Ekhart C, Rodenhuis S, Smits PHM, Beijnen JH, and Huitem, ADR. An overview of the relations between polymorphisms in drug metabolising enzymes and drug transporters and survival after cancer drug treatment. Cancer Treat Rev. 2009; 35: 18-31.

20. Vivona D, Bueno CT, Lima LT, Hirata RDC, Hirata $\mathrm{MH}$, Luchessi $\mathrm{AD}$, et al. $A B C B 1$ haplohaplotype is associated with major molecular response in chronic myeloid leukemia patients treated with standard-dose of imatinib. Blood Cells Mol Dis. 2012; 48: 132-136.

21. Rubis B, Holysz H, Barczak W, Gryczka R, Lacinski $\mathrm{M}$, et al. Study of $A B C B 1$ polymorphism frequency in breast cancer patients from Poland. Pharmacol Rep. 2012; 64: 1560-1566. 2012.

22. Johne A, Kopke K, Gerloff T, Mai I, Rietbrock S, Meisel C, et al. Modulation of steady-state kinetics of digoxin by haplotypes of the P- glycoprotein MDRI gene. Clin Pharmacol Ther. 2002; 72(5): 584-94.

23. Chowbay B, Cumaraswamy S, Cheung YB, Zhou Q, Lee EJ. Genetic polymorphisms in MDR1 and CYP3A4 genes in Asians and the influence of MDRl haplotypes on cyclosporin disposition in heart transplant recipients. Pharmacogenetics. 2003; 13(2): 89-95.

24. Yi SY, Hong KS, Lim HS, Chung JY, Oh DS, Kim JR, et al. A variant 2677A allele of the MDRl gene affects fexofenadine disposition. Clin Pharmacol Ther. 2004; 76(5): 418-27.

25. Tsai CJ, Sauna ZE, Kimchi-Sarfaty C, Ambudkar SV, Gottesman MM, Nussinov R. Synonymous mutations and ribosome stalling can lead to altered folding pathways and distinct minima. J Mol Biol. 2008; 383: 281-291.

26. Crettol S, Deglon JJ, Besson J, Croquette-Krokar M, Hammig R, Gothuey I, et al. $A B C B 1$ and cytochrome P450 genotypes and phenotypes: influence on methadone plasma levels and response to treatment. Clin Pharmacol Ther. 2006; 80: 668-681.

27. Shi YY, He L. SHEsis, a powerful software platform for analyses of linkage disequilibrium, haplotype construction, and genetic association at polymorphism loci. Cell Res. 2005; 15(2): 97-8.

28. Li Z, Zhang Z, He Z, Tang W, Li T, Zeng Z, et al. A partition-ligation-combination-subdivision EM algorithm for haplotype inference with multiallelic markers: update of the SHEsis (http://analysis.bio-X-cn). Cell Res. 2009; 19(4): 519-23.

29. Sai K, Kaniwa N, Itoda M, Saito Y, Hasegawa R, Komamura, et al. Haplotype analysis of $A B C B 1$ $M D R 1$ blocks in a Japanese population reveals genotype-dependent renal clearance of irinotecan. Pharmacogenetics. 2003; 13: 741-757.

30. Wasilewska A, Zalewski G, Chyczewski L, and Zoch-Zwierz W. MDRl gene polymorphisms and clinical course of steroid-responsive nephrotic syndrome in children. Pediatr Nephrol. 2007; 22: 44-51.

31. Xu P, Jiang ZP, Zhang BK, Tu JY, and Li HD. Impact of MDRl haplotypes derived from C1236T, $\mathrm{G} 2677 \mathrm{~T}=\mathrm{A}$ and $\mathrm{C} 3435 \mathrm{~T}$ on the pharmacokinetics of single-dose oral digoxin in healthy Chinese volunteers. Pharmacology. 2008; 82: 221-227.

32. Pechandova D, Buzkova K H, Slanar O, and Perlı'k F. Polymorphisms of the MDRl gene in the Czech population. Folia Biol (Praha). 2006; 52: 184-189.

33. Komoto C, Nakamura T, Sakaeda T, Kroetz DL, Yamada T, et al. MDRl haplotype frequencies in Japanese and Caucasian, and in Japanese patients with colorectal cancer and esophageal cancer. Drug Metab Pharmacokinet. 2006; 21: 126-132.

34. Lee SS, Kim SY, Kim WY, Thi-Le H, Yoon YR, Yea SS and Shin JG. MDRl genetic polymorphisms and comparison of MDRl haplotype profiles in Korean and Vietnamese populations. Ther Drug Monit. 2005; 27: 531-535.

35. Halim Salem A, Ali M, Ibrahim A and Ibrahim M. Genotype and Allele Frequencies of MDR-1 Gene Polymorphism in Jordanian and Sudanese Populations American Journal of Medicine Studies. 2014; 1: 19-23.

36. Gonzalez TP, Mucenic T, Brenol JC, Xavier RM, Schiengold M, Chies JA. ABCB1 C1236T, G2677T/A and $\mathrm{C} 3435 \mathrm{~T}$ polymorphisms in systemic lupus erythematosus patients. Braz J Med Biol Res. 2008; 41(9): 769-72. 
37. Sipeky C, Csongei V, Jaromi L, Safrany E, Maasz A, Takacs I, et al. Genetic variability and haplotype profile of MDR1 (ABCB1) in Roma and Hungarian population samples with a review of the literature. Drug Metab Pharmacokinet. 2011; 26(2): 206-15.

38. Marie-Genica Consortium on Genetic Susceptibility for Menopausal Hormone Therapy Related Breast Cancer Risk. "Polymorphisms in the BRCA1 and $A B C B 1$ genes modulate menopausal hormone therapy associated breast cancer risk in postmenopausal women. Breast Cancer Res Treat. 2010; 120 (3): 727-736.

39. Kafka A, Sauer G, Jaeger C, Grundmann R, Kreienberg R, Zeillinger R, Deissler H. Polymorphism C3435T of the MDR-1 gene predicts response to preoperative chemotherapy in locally advanced breast cancer. Int J Oncol. 2003; 22(5): 1117-21.

40. Simon T, Verstuyft C, Mary-Krause M, Quteineh L, Drouet E, Meneveau N, et al. Genetic determinants of esponse to clopidogrel and cardiovascular events. $\mathrm{N}$ Engl J Med. 2009; 360 (4): 363-375.

41. Kim DH, Park JY, Sohn SK, Lee NY, Baek JH, Jeon $\mathrm{SB}$, et al. Multidrugresistence-1 gene polymorphisms associated with treatment outcomes in de novo acute myeloid leukemia._Int J Cancer. 2006; 118(9): 2195201.

42. Siddiqui A, Kerb R, Weale ME, Brinkmann U, Smith A, Goldstein DB, et al. Association of multidrug resistance in epilepsy with a polymorphism in the drugtransporter gene $A B C B 1$. N Engl J Med. 2003; 348(15): 1442-8.

43. E Shon JH, Yoon YR, Hong WS, Nguyen PM, Lee SS, Choi YG, et al. Effect of itraconazole on the pharmacokinetics and pharmacodynamics of fexofenadine in relation to the MDRl genetic polymorphism. Clin Pharmacol Ther. 2005; 78: 191-201.

44. F Cavaco I, Gil JP, Gil-Berglund E and Ribeiro V. CYP3A4 and MDR1 alleles in a Portuguese population. Clin Chem Lab Med. 2003; 41: 1345-1350.

45. Pan JH, Han JX, Wu JM, Huang HN, Yu QZ and Sheng LJ. MDRl single nucleotide polymorphism $\mathrm{G} 2677 \mathrm{~T}=\mathrm{A}$ and haplotype are correlated with response to docetaxelcisplatin chemotherapy in patients with non-small-cell lung cancer. Respiration. 2009; 78: 49-55.

46. Potocnik U, Glavac D and Dean M. Common germline $M D R 1 / A B C B 1$ functional polymorphisms and haplotypes modify susceptibility to colorectal cancers with high microsatellite instability. Cancer Genet Cytogenet. 2008; 183: 28-34.

47. Wang D, Johnson AD, Papp AC, Kroetz DL and Sadee W. Multidrug resistance polypeptide 1 (MDRl, $A B C B 1$ ) variant $3435 \mathrm{C}>\mathrm{T}$ affects mRNA stability. Pharmacogenet. Genomics. 2005; 15: 693-704.

48. Kim RB, Leake BF, Choo EF. et al. Identification of functionally variant $M D R 1$ alleles among European Americans and African Americans. Clin. Pharmacol. Ther. 2001; 70: 189-199.

49. Urayama KY, Wiencke JK, Buffler PA, Chokkalingam AP, Metayer C and Wiemels JL. MDRl gene variants, indoor insecticide exposure, and the risk of childhood acute lymphoblastic leukemia. Cancer Epidemiol Biomarkers Prev. 2007; 16: 1172-1177.
50. Kurzawski M, Pawlik A, Gornik W and Drozdzik M. Frequency of common $M D R l$ gene variants in a Polish population. Pharmacol. Rep. 2006; 58: 35-40.

51. Kroetz DL, Pauli-Magnus C, Hodges LM. et al. Sequence diversity and haplotype structure in the human ABCB1 (MDR1, multidrug resistance transporter) gene. Pharmacogenetics. 2003; 13: 481-494.

52. Gümüş-Akay G, Rüstemoğlu A, Karadağ A, Sunguroğlu A. Haplotype-based analysis of $M D R 1 / A B C B 1$ gene polymorphisms in a Turkish population. DNA Cell Biol. 2010; 29: 83-90.

53. Bandur S, Petrasek J, Hribova P, Novotna E, Brabcova I and Viklicky O. Haplotypic structure of $A B C B 1 / M D R 1$ gene modifies the risk of the acute allograft rejection in renal transplant recipients. Transplantation. 2008; 86(9): 1206-13.

54. Wong M, Evans S, Rivory LP, Hoskins JM, Mann GJ, Farlow D, et al. Hepatic technetium Tc 99mlabeled sestamibi elimination rate and $A B C B 1$ (MDRI) genotype as indicators of $A B C B 1$ (P-glycoprotein) activity in patients with cancer. Clin Pharmacol Ther. 2005; 77(1): 33-42.

55. Panczyk M, Balcerczak E, Piaskowski S, Jamroziak K, Pasz-Walczak G, Mirowski M. ABCB1 gene polymorphisms and haplotype analysis in colorectal cancer. Int J Colorectal Dis. 2009; 24(8): 895-905.

56. Sai K, Kaniwa N, Itoda M, Saito Y, Hasegawa R, Komamura K, et al. Haplotype analysis of $A B C B 1 / M D R 1$ blocks in a Japanese population reveals genotype-dependent renal clearance of irinotecan. Pharmacogenetics. 2003; 13(12): 741-57.

57. Cascorbi I. Role of pharmacogenetics of ATP-binding cassette transporters in the pharmacokinetics of drugs. Pharmacol. Ther. 2006; 112: 457-473.

58. Tan E.K, Drozdzik M, Bialecka M. et al. Analysis of MDRl haplotypes in Parkinson's disease in a white population. Neurosci. Lett. 2004; 372: 240-244.

59. Gaikovitch EA, Cascorbi I, Mrozikiewicz PM et al. Polymorphisms of drug-metabolizing enzymes $C Y P 2 C 9$, CYP2C19, CYP2D6, CYP1A1, NAT2 and of P-glycoprotein in a Russian population. Eur. J. Clin. Pharmacol. 2003; 59: 303-312.

60. Ameyaw MM, Regateiro F, Li T. et al. MDRl pharmacogenetics: frequency of the C3435T mutation in exon 26 is significantly influenced by ethnicity. Pharmacogenetics 2001; 11: 217-221.

61. Onnie CM, Fisher SA, Pattni R, Sanderson J, Forbes A, Lewis CM, Mathew CG. Associations of allelic variants of the multidrug resistance gene $(A B C B 1$ or $M D R 1)$ and inflammatory bowel disease and their effects on disease behavior: a case-control and meta-analysis study. Inflamm Bowel Dis. 2006; 12(4): 263-71.

62. Ho GT, Nimmo ER, Tenesa A, et al. Allelic variations of the multidrug resistance gene determine susceptibility and disease behavior in ulcerative colitis. Gastroenterology. 2005; 128: 288-296.

63. Jeannessona E, Albertinia L, Siesta G, Gomesb AM, Ribeirob V, Aslanidisc C, et al. Determination of $A B C B 1$ polymorphisms and haplotypes frequencies in a French population Fundamental and Clinical Pharmacology. 2007; 21: 411-418. 
64. Bernal ML, Sinues B, Fanlo A and Mayayo E. Frequency distribution of C3435T mutation in exon 26 of the MDR1 gene in a Spanish population. Ther. Drug Monit. 2003; 25: 107-111.

65. Vicente J, Sinues B, Fanlo A, Vasquez P, Medina JC, Martinez-Jarreta B. Polymorphism C3435T of the MDRl gene in Central Americans and Spaniards. Mol Biol Rep. 2008; 35(3): 473-8.

66. Furuno T, Landi MT, Ceroni M, et al. Expression polymorphism of the blood-brain barrier component $\mathrm{P}$ glycoprotein $(M D R l)$ in relation to Parkinson's disease. Pharmacogenetics. 2002; 12: 529-534.

67. Palmieri $\mathrm{O}$, Latiano A, Valvano R, D'Incà R, Vecchi M, Sturniolo GC, Saibeni S, et al. Multidrug resistance 1 gene polymorphisms are not associated with inflammatory bowel disease and response to therapy in Italian patients. Aliment Pharmacol Ther. 2005; 22(11-12): 1129-38.

68. Petrova DT, Nedeva P, Maslyankov S, Toshev S, Yaramov N, Atanasova S, et al. No association between MDR1 (ABCB1) 2677G > $\mathrm{T}$ and $3435 \mathrm{C}>\mathrm{T}$ polymorphism and sporadic colorectal cancer among Bulgarian patients. Cancer Res Clin Oncol. 2008; 134(3): 317-22.

69. Milojkovic M, Stojnev S, Jovanovic I, Ljubisavljevic S, Stefanovic V, Sunder-Plassman R. Frequency of the C1236T, G2677T/A and C3435T MDRl gene polymorphisms in the Serbian population. Pharmacol Rep. 2011; 63(3): 808-14.

70. Sabahi Z, Salek R, Heravi R, Mosaffa F, Avanaki Z and Behravan J. Association of gastric cancer incidence with $M D R 1$ gene polymorphism in an ethnic Iranian population. Indian J Cancer. 2010; 47: 317-321.

71. Hamdy S I, Hiratsuka M, Narahara K, Endo N, ElEnany M, Moursi N, et al. Genotype and allele frequencies of TPMT, NAT2, GST, SULTIA1 and MDR-1 in the Egyptian population. Br J Clin Pharmacol. 2003; 55: 560-569.

72. Sapmaz A, Ozen Karatayli SC, Dağli U, Kiliç ZM, Törüner M, Celik Y, et al. Effects of polymorphism in G2677T/A triallelic region of MDRl gene in Turkish patients with inflammatory bowel disease. Turk J Gastroenterol. 2008; 19(3): 168-73.

73. Omoto CK, Akamura TN, Akaeda TS, Roetz DLK, Amada TY, Matsu HO, et al. Regular article MDRI haplotype frequencies in Japanese and Caucasian, and in Japanese patients with colorectal cancer and esophageal cancer. Drug Metab Pharmacokinet. 2006; 21: 126-132.

74. Horinouchi M, Sakaeda T, Nakamura T, Morita Y, Tamura T, Aoyama N, et al. Significant genetic linkage of MDRl polymorphisms at positions 3435 and 2677: functional relevance to pharmacokinetics of digoxin. Pharm Res. 2002; 19(10): 1581-5.

75. Zheng H, Webber S, Zeevi A, Schuetz E, Zhang J, Lamba J, et al. The MDR1 polymorphisms at exons 21 and 26 predict steroid weaning in pediatric heart transplant patients. Human Immunol. 2002; 63: 765770.

76. Li D, Zhang GL, Lou YQ, Li Q, Wang X, Bu XY. Genetic polymorphisms in MDRl and $C Y P 3 A 5$ hap- lotype in mainland Chinese Han, Uygur and Kazakh ethnic groups. J Clin Pharm Ther. 2007; 32(1): 89-95.

77. Zhang WX, Chen GL, Zhang W, Tan ZR, Liu J, Zhou G, et al. MDRl genotype do not influence tha absorption of a single oral dose of $100 \mathrm{mg}$ talinolol in healthy Chinese males. Clin Chim Acta. 2005; 359(12): 46-52.

78. Kassogue Y, Dehbi H, Nassereddine S, Quachouh M and Nadifi S. Genotype Variability and Haplotype Frequency of $M D R 1$ ( $A B C B 1)$ Gene Polymorphism in Morocco. DNA and Cell biology. 2013; 32(10): 582-8.

79. Http://www.ncbi.nih.gov/pojects/SNP/snp_ref.cgi? $\mathrm{rs}=1128503$

80. Kimchi-Sarfaty C, Marple AH, Shinar S, Kimchi AM, Scavo D, Roma MI, et al. Ethnicity-related polymorphisms and haplotypes in human $A B C B 1$ gene. Pharmacogenomics. 2007; 8(1): 29-39.

81. Estrela RC, Ribeiro FS, Carvalho RS, Gregório SP, Dias-Neto E, Struchiner CJ, Suarez-Kurtz G. Distribution of $A B C B 1$ polymorphisms among Brazilians: impact of population admixture. Pharmacogenomics. 2008; 9(3): 267-76.

Резиме

(MDP1)

АБЦБ1

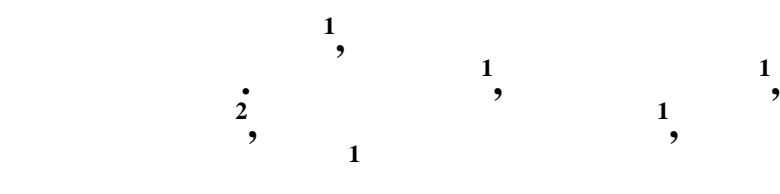

${ }^{1}$ Институт за фармацевтска хемија, Фармацевтски факултет, Универзитет „Св. Кирил и Методиј“, Скопје, Р. Македонија

${ }^{2}$ Универзитетска клиника за психијатрија, Медицински факултет, Универзитет „Св. Кирил и Методиј“, Скопје, Р. Македонија

Главна цел на оваа студија е да направи евалуација на најчесто испитуваните полиморфизми на $\quad l(1$, П-гликопротеин) генот во популацијата во Република Македонија и да ги спореди алелните и хаплотипските фреквенции со глобалните географски податоци за пријавените фреквенции во различни етнички популации.

Во студијата беа вклучени 107 здрави индивидуи со етничко македонско потекло. Со метода на Real-Time PCR беше направена анализа на генотиповите на АБЦБ1 за три полиморфизми C1236T [rs1128503], G2677A/T [rs2032582] и C3435T [rs1045642]. Добиените алелни фреквенции за овие три снипа во македонската етничка 
популација беа слични со веќе публикуваните за други европски народи од бела раса. Генотипските фреквенции што беа добиени изнесува $33,6 \%$ за $1236 \mathrm{CC}, 44,9 \%$ за $1236 \mathrm{CT}$ и $21,5 \%$ за 1236 ТT во егзон $12 ; 32,7 \%, 44,9 \%$ и $22,4 \%$ за $2677 \mathrm{GG}, 2677 \mathrm{GT}$ и $2677 \mathrm{GT}$ соодветно во егзон 21 ; и $25,2 \%$ за $3435 \mathrm{CC}, 52,3 \%$ за $3435 \mathrm{CT}$ за $22,5 \%$ за 3435TT во егзон 26. Силен Linkage Disequilibrium (LD) беше потврден со резултатите од нашата студија помеѓу трите еднонуклеотидни полиморфизми (Single Nucleotide Polymorphisms-SNPs), при што највисока асоцираност беше потврдена за C1236T и G2677T ((D'= $\left.0,859, \mathrm{r}^{2}=0,711\right)$. Идентификувани се осум различни хаплотипови со најголема застапеност на CGC-хаплотипот (45,3\%). Нашата студија е прва која ја пријавува дистрибуцијата на АБЦБ1 алелните, геотипските и хаплотипските фреквенциво популацијата со етничкомакедонско потекло во Република Македонија. Добиените резултати може да помогнат во предвидувањето на различниот терапевтски одговор при употреба на лекови што се супстрати на П-гликопротеинот. Дополнително, во ерата на индивидуализирана медицина познавањето на генотипот на Пгликопротеинот може да биде добар предиктивен маркер за определување на суппопулациите со зголемена предиспозиција кон одредени заболувања.

лучни зборови: АБЦБ1 (МДР1), П-гликопротеин, C1236T, G2677A/T, C3435T, интеретнички разлики, хаплотипови, македонска популација. 